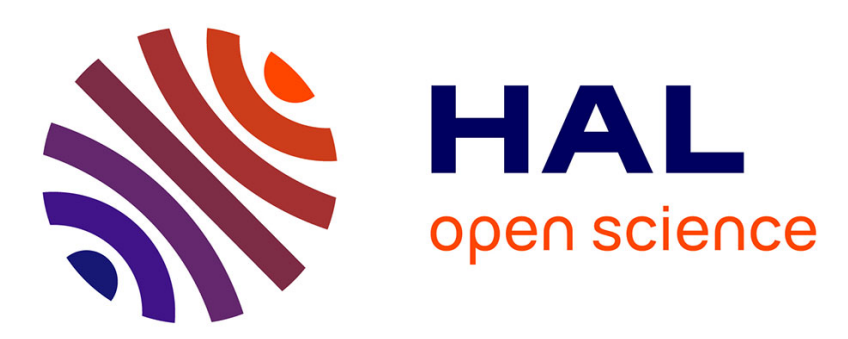

\title{
Organisation of the soil mantle in tropical southeastern Brazil (Serra do Mar) in relation to landslides processes.
}

\author{
S. Furian, Laurent Barbiero, René Boulet
}

\section{To cite this version:}

S. Furian, Laurent Barbiero, René Boulet. Organisation of the soil mantle in tropical southeastern

Brazil (Serra do Mar) in relation to landslides processes.. CATENA, 1999, 38, pp.65-83. hal-00364002

\section{HAL Id: hal-00364002 \\ https://hal.science/hal-00364002}

Submitted on 25 Feb 2009

HAL is a multi-disciplinary open access archive for the deposit and dissemination of scientific research documents, whether they are published or not. The documents may come from teaching and research institutions in France or abroad, or from public or private research centers.
L'archive ouverte pluridisciplinaire HAL, est destinée au dépôt et à la diffusion de documents scientifiques de niveau recherche, publiés ou non, émanant des établissements d'enseignement et de recherche français ou étrangers, des laboratoires publics ou privés. 


\section{Organisation of the soil mantle in tropical southeastern Brazil (Serra do Mar) in relation to landslides processes.}

Sônia Furian

Depto de Geografia - USP-FFLCH

Cidade universitaria C.P. 8105

Cep: 05508-900 Sao Paulo-SP, Brazil

And

INRA-ENSA. Laboratoire des sciences du sol 65 rue de St Brieuc

35042 Rennes Cedex, France

\section{Laurent Barbiéro}

IRD exORSTOM, centre de Hann, BP 1386 Dakar, Sénégal.

\section{René Boulet}

IRD exORSTOM - Instituto de geociencias - DGG - USP

C.P. 11348

Cep: 05 422-970 Sao Paulo-SP, Brazil

Correspondence: Laurent Barbiéro

barbiero@1mtg.obs-mip.fr 


\begin{abstract}
The Serra do Mar complex in the southeastern Brazil is subject to frequent landslides especially on the Atlantic coast. The three dimensional organisation of the soil was studied in a 56 ha representative catchment. Upslope in situ soil material has developed from the parent rock, and downslope the soil has resulted from landslide processes. The soil mantle upslope is mainly characterised by slowly permeable kaolinitic horizons within a thick gibbsitic weathering horizon. The field and microscopic relationships between the two suggest that the kaolinitic horizon has evolved at the expense of the gibbsitic material. Resilication of gibbsite to form kaolinite is postulated in this environment. The kaolinitic horizons are overlain by a microaggregated horizon. The difference in porosity and water movement between these two horizons was estimated by density measurements, mercury porosimetry, image processing and calculation of water retention and shrinkage curves. The results indicate that water is retained briefly within the microaggregated horizon during intensive rainfall. Because of the inclination of the kaolinitic horizon, any excess water within it flows laterally downslope and accumulates in the lowest part of the slope. This leads to landslipping, the main process of landform development in the region.
\end{abstract}

Keywords: Oxisol, Gibbsite, Kaolinite, Landslides, Brazil.

\title{
1. Introduction
}

Landslides are very frequent in southeastern Brazil. Catastrophic examples are reported almost every year: Rio de Janeiro-RJ (1805, 1966, 1967, 1988), Santos-SP (1928), Cubatao-SP (1946), Via Anchieta-SP (1956, 1964, 1966), Guaratuba-PR (1968), Campos do Jordao (1972), CaraguatatubaSP (1944, 1967) Ubatuba-SP (1942, 1943, 1949), Tubarao-SC (1975), on the road Rio de JaneiroSantos (1974, 1975, 1976, 1981, 1982, 1984, 1985) (Bigarella et al., 1965; Felicissimo, 1967; Cruz, 
1974; Guidicini and Nieble, 1976; Guidicini and Iwasa, 1976; De Ploey and Cruz, 1979; Souza Sobrinho, 1988). Also there are many small landslides that do not involve loss of life or damage to property. Their real importance is unknown in areas with sparse population. Most previous studies have involved statistical estimates of the location of landsides and the conditions of climate, bedrock geology, slope steepness, vegetation cover and human occupation leading to their occurrence. This has shown that landslides occur principally in the Serra do Mar complex, at the end of the rainy season when rainfall is most intense. Guidicini and Iwasa (1976) showed that the probability of landsliding is increased when rainfall exceeds $250 \mathrm{~mm}$ in $24 \mathrm{hr}$, regardless of antecedent rainfall. Cruz (1974) emphasised the role of slope steepness; slopes exceeding $40 \%$ encourage landslides, regardless of vegetation cover and human occupation. Landslide processes occur mainly on the lowest third of the slope. Small landslides occur in the middle slope and readjust the slope topography after the main landslides have occurred downslope. Therefore, they contribute to landscape evolution. Although more than $99 \%$ of the rainfall infiltrates (Furian, 1987), the flows of water in the soil mantle are unknown. Even the structure and other profile characteristics of the soil involved in the landslides are poorly understood. De Ploey and Cruz (1979) concluded that the hydrology of the slopes should be studied in more detail.

The aim of this paper is to describe the nature and origin of the soil mantle and to relate these to landslide processes.

\section{Site description}

The studied area is located at $23^{\circ} \mathrm{S}$ in the Brazilian humid tropical zone, between the Serra do Mar and the Atlantic Plateau in the eastern part of Sao Paulo State. The fieldwork was concentrated on a small (56 ha) catchment of the River Paraibuna in the district of Cunha, known as the "D" catchment in the Serra do Mar State Park (Fig.1). Cunha is part of the granite-gneiss high plateaux of the Serra do Mar. Uplifted since the Oligocene (Almeida, 1976), these plateaux belong, with the 
Serra da Mantiqueira, to the uppermost surface of the block mountains of southeastern Brazil's Atlantic margin. The chemical weathering of the crystalline Precambrian basement has resulted in sandy loamy regoliths with a maximum thickness of $15 \mathrm{~m}$ (Bigarella et al., 1965).

Recent evolution of slopes in the Serra do Mar has been mainly controlled by mass movements, including slumping and planar slides in the regolith, rockfalls and rockslides (De Ploey and Cruz, 1979). Steeper slopes of 70-100\% are related to major faults in the crystalline bedrock. Less steep slopes are 40-60\%. The climate belongs to type Cwa of Köppen (Furian and Pfeifer, 1986) with orographic influences. Annual precipitation ranges from 2000 to $2500 \mathrm{~mm}$, with a rainy season from September to March giving $71 \%$ of the annual rainfall. The natural vegetation is rain forest of the "Atlantic forest" domain which still covers large parts of the Serra do Mar.

\section{Methods}

The soil pattern of the slope was studied in detail, emphasising the geometrical relationships between the different soil horizons and genesis of the soil types (Boulet et al., 1982). This approach has often been used to understand the links between morphogenesis and pedogenesis (Lucas, 1989; Fritsch and Fitzpatrick, 1994; Furian, 1994; Boulet et al., 1995). The two-dimensional soil pattern was determined in transects, one along the crest line (1) and three down the slope (2, 3 and 5)(Fig. 2). A map of the area was drawn by projecting the limits of the different horizons and selected soil features onto a horizontal plane. Soil horizons were identified, described and sampled for laboratory analysis from 47 auger holes and 24 soil pits generally located over lateral transitions between horizons.

Undisturbed blocks were collected and impregnated with an acetone-diluted ("Crystic") polyester resin after dehydration by acetone exchange (Delaye, 1984), and vertical thin sections (70 x 110 mm) were made and described according to Brewer (1976) and Bullock et al. (1985). In order to visualise the macroporosity, a fluorescent dye (Ciba-Geigy Uvitex OB) was added to the resin. 
Some samples were collected for SEM (XL 20 Philips at $15 \mathrm{kV}$ ) observations and analyses of aggregates (LINK Analytical eXL energy dispersive X-Ray system).

Particle density was measured in 5 replicates of oven dried samples using a water picnometer. Bulk density was measured on $251 \mathrm{~cm}^{3}$ calibrated cylindrical samples by weighing soil previously dried at $105^{\circ} \mathrm{C}$. Total porosity was computed from these data and is expressed as a percentage of the soil core volume.

The pore size distribution, between 0.0037 and $100 \mu \mathrm{m}$ equivalent radii, was studied with a CARLO ELBA 2000 mercury porosimeter using air-dried centimetric aggregates outgassed at room temperature.

Images from thin sections were captured by reflected UV light (Hallaire and Curmi, 1994), which caused pore space to appear as bright areas on the dark background. Negative images are presented here. Images were digitalised using the VISILOG system with 768 x 576 pixels, a spectral resolution of 256 grey levels and a pixel size of $10 \mu \mathrm{m}$. The pores were identified by a simple threshold partition and the macroporosity was calculated as a volume percentage from the proportion of pore pixels (Wiebel, 1979). Overall macropore connectivity in each thin section was classified visually as low, medium or high.

Water retention curves were determined on $5-10 \mathrm{~cm}^{3}$ samples by sorption through membrane filters according to Tessier and Berrier (1979) for the low suction range ( $\mathrm{pF} 1-3)$ and by pressure membrane equipment (Tessier, 1978) for greater suctions. The shrinkage of the soil samples was slight, so the shrinkage curves were estimated from the apparent volumes at $\mathrm{pF} 2$ and 6 , using the kerosene method developed by Monnier et al. (1973).

\section{Catena organisation}

Figure 2 shows the distribution of soil horizons in sequence 2, which can be divided into two zones, the upslope and downslope domains. 


\subsection{Upslope domain}

The upslope domain consists of a ferrallitic soil $12 \mathrm{~m}$ thick. It is mainly composed of a sandy gibbsitic weathered material derived from the parent rock (G Horizon). The original mineral structures and that of the rock itself are preserved in gibbsite pseudomorphs. This results in a gibbsitic horizon with a box-work structure (Figs. 3 and 4). The polysynthetic twinning of plagioclases and the cleavage of amphiboles are also preserved in the gibbsite, indicating that the formation of gibbsite was the first stage in weathering of the parent rock. Only quartz and muscovite were unaltered at this stage. The structure of the parent rock is also preserved in millimetric gibbsitic veins that probably infilled fissures in the parent rock.

This gibbsitic weathering level (G horizon) is overlain by a pebbly and blocky horizon composed of ferruginised gibbsitic material. The structure of the parent rock is still preserved in the blocks. Although the soil fauna has burrowed into the superficial horizons, it is still possible to identify relics of the millimetric gibbsitic veins.

In the lower part of the upslope domain, a compact clay loam kaolinitic horizon (here called $\mathrm{K}$ horizon) occurs within the gibbsitic horizon ( $\mathrm{G}$ horizon). It is tongue-shaped and is truncated by the superficial porous microaggregated horizons ( $\mathrm{mh} 1$ and $\mathrm{mh} 2)$. These are conformable with the slope topography. In thin sections, the mh1 horizon seems to have arisen from the destruction of the gibbsitic box-work structure, whereas the mh2 horizon is composed of biofabrics and is burrowed by the soil fauna. A second clay loam kaolinitic horizon (K horizon) appears downslope at 2-2.5 m depth, also within the sandy gibbsitic weathering horizon ( $\mathrm{G}$ horizon) but beneath the first $\mathrm{K}$ horizon.

Detailed study of the contact between the K and G horizons showed that the structure of the $\mathrm{K}$ horizon truncates that of the $\mathrm{G}$ material, indicating that the latter developed first from the bedrock and subsequently changed into a kaolinitic material (Fig. 5). At this contact, the gibbsite has lost its optical properties becoming isotropic, acquiring a pale yellow colour, decreasing in crystal size and 
losing its box-work structure. Evidence of dissolution of quartz and gibbsite is observed by SEM (Figs. 6, 7, 8 and 9). Different morphological types of gibbsite are observed, from euhedral crystals to those showing extensive surface etching by dissolution (Figs. 6 and 7). Therefore, the silica and alumina necessary for kaolinite formation could have been supplied by dissolution of gibbsite and quartz. Destruction of gibbsite in ferrallitic soils was originally proposed by Delvigne (1965) in an Ivory Coast catena, and has been observed by Eswaran and Daud (1980) in gibbsitic nodules in the surface horizon of the Malacca series in Malaysia. Keller and Clark (1984) observed resilication of bauxite producing kaolin in Arkansas. Lucas et al. (1989) also described resilication in Amazonian bauxites.

\subsection{Downslope domain}

The downslope domain (not detailed in Fig. 2) is composed of superficial horizons overlying a clay horizon with many randomly oriented blocks. The clay horizon rests directly and abruptly on the hard bedrock. Remnants of box-work gibbsite occur, but are frequently associated with unweathered minerals such as hornblende, other amphiboles, microcline and biotite (Fig. 10).

\subsection{Mid-slope transition}

The upslope soil cover clearly differs from the downslope, and the contact between the two is abrupt. On the middle part of the slope, the upslope soil cover is truncated over its whole thickness by the material of the downslope cover (Fig. 2).

\section{Genesis of the soil cover}

The observations suggest the following model for genesis of the soil cover. The upslope soil cover is derived from in situ gibbsitic weathering of the bedrock, the structure of which is preserved in the soil, even up to the surface horizons where gibbsitic veins occur. In contrast, in the 
downslope domain the blocks do not preserve the orientation of the parent rock. Gibbsite is associated with unweathered minerals, indicating a mixture of pedogenic materials which have suffered different weathering histories. We suggest that the downslope material is colluvial and results partly from reworking by landslide processes of a material similar to that observed in the upslope domain.

One of the main features of the whole soil system is the presence of kaolinitic tongues ( $\mathrm{K}$ horizon) into the gibbsitic weathering material ( $\mathrm{G}$ horizon). Figure 11 shows the limits of the $\mathrm{K}$ horizons and of the colluvium on the slope. The distribution of the $\mathrm{K}$ horizons is complex; they occupy a large part of the soil mantle, but are truncated downslope by the colluvium.

\section{Physical properties of the horizons and water circulation in the catena}

The dissolution of gibbsite and quartz and the formation of kaolinite generate tongues arranged like tiles on a roof. They are likely to be slowly permeable and to influence the flow of water on the slope. Table 1 shows the physical and hydrological characteristics of the gibbsitic-weathering horizon ( $\mathrm{G}$ horizon), the kaolinitic horizon ( $\mathrm{K}$ horizon) and the microaggregated $\mathrm{M}$ horizons overlying the $\mathrm{K}$ horizons. Mercury injection curves, macroporosity identified by image processing and water retention and shrinkage curves are presented in Figs 12, 13 and 14.

During the fieldwork, waterlogging after rainfall was observed in the $\mathrm{M}$ horizons overlying the $\mathrm{K}$ horizons. This suggests a severe decrease in the vertical infiltration rate at this contact. Density measurements indicated that the total porosity increases from the $\mathrm{G}(40 \%)$ to the $\mathrm{K}(51 \%)$ and $\mathrm{M}$ (64\%) horizons, and the mercury injection curves show that the pore size distributions are also significantly different. The $\mathrm{G}$ and $\mathrm{M}$ horizons exhibit a bimodal distribution of pore sizes, corresponding to intra- and inter-aggregate pores as in other ferrallitic soils (Cambier and Prost, 1981; Curmi et al., 1994), whereas the K horizon has a unimodal distribution, which is almost entirely microporosity ( $90 \%$ of the pores intruded by mercury). The image processing also revealed 
significant differences in macroporosity, corresponding to $24.5 \%$ with medium connectivity in G, 9.3\% with low connectivity in $\mathrm{K}$, and $31.6 \%$ with high connectivity in M. Circulation of water is possible in $\mathrm{G}$, but between $\mathrm{M}$ and $\mathrm{K}$ there is a clear decrease in macroporosity. $\mathrm{K}$ is slowly permeable because of the weak connection between macropores. This allows lateral circulation into $\mathrm{M}$, which is consistent with the field observations.

The water retention and shrinkage curves for these horizons confirm the information given by the macroporosity measurements. At low suction (pF3), the microaggregated M horizon retains only 50 $\%$ water (Table 1), whereas the kaolinitic $\mathrm{K}$ horizon is almost saturated $(87 \%)$. This means that a large proportion of the porosity in the $\mathrm{M}$ horizons could be briefly occupied by water during intense rainfall.

The pore size distribution suggests that some vertical drainage is possible in the gibbsitic material, but that most of the water moves laterally over the $\mathrm{K}$ horizons. However, this conclusion should be confirmed by an in situ analysis of the slope hydrology (Grimaldi and Boulet, 1990).

\section{Identification of the landslide risk}

All the observations and measurements emphasize the contribution of weathering and pedogenesis to landscape evolution. The development of the $\mathrm{K}$ horizons seems to be the key to initiation of landslide processes. A three-stage model of increasing development of $\mathrm{K}$ horizons (Fig. 15 ) is proposed. In the first stage (a), the K horizons are thin and separated and vertical drainage in the sandy gibbsitic weathering material predominates. Little lateral flow is observed and the water infiltrates homogeneously along the slope. The risk of landslide is low. In the second stage (b), the K horizons are more strongly developed and the proportion of lateral subsurface drainage increases. The risk of landslide then also increases. In the third stage (c), the $\mathrm{K}$ horizons are strongly developed and the subsurface lateral drainage predominates, canalizing the water downslope during intense rainfall. The water in the macroporosity of the $\mathrm{M}$ horizon can create a consequent overload 
in the lower third of the slope. The mass of retained water, within a $0.3 \mathrm{~m}$ thick microaggregated horizon, increases from $100 \mathrm{~kg} / \mathrm{m}^{2}$ at $\mathrm{pF} 3$ to $200 \mathrm{~kg} / \mathrm{m}^{2}$ at $\mathrm{pF} 1$, increasing the slope instability as described by Moyersons (1989) in Rwanda. The risk of landslide is then very high. As the K horizons evolve laterally and upslope at the expense of the G horizon, the mass of water and the risk of landslide increase with the development of this pedological system.

\section{Conclusion}

This work emphasises the contribution of the soil system to landslide processes, and explains the relationships between landslides and environmental conditions. Landslides occur mainly on the Atlantic margin of the Serra do Mar, generally on the lower third of the slope and at the end of the rainfall season after prolonged heavy rainfall. The soil cover consists of clay loam kaolinitic $\mathrm{K}$ horizons arranged like the tiles of a roof, within a thick sandy gibbsitic horizon. The $\mathrm{K}$ horizons are overlain by a very porous microaggregated horizon. On the studied slope, this in situ soil cover is truncated downslope by a soil cover arising from landslides, in which many remnants of the upslope soil cover are preserved.

The measurements of total porosity, pore size distribution, connectivity of macropores, water retention and shrinkage curves and the field observations suggest that the drainage is vertical into the gibbsitic weathering material ( $\mathrm{G}$ horizon), but lateral in the microaggregated $\mathrm{M}$ horizons over the kaolinitic horizon (K horizon), thus precluding a homogeneous distribution of the water in the soil cover. Retention curves reveal that the $\mathrm{M}$ horizons can retain briefly a large quantity of water during intensive rainfall, and this overloads the lower third of the slope generating landslides.

This study indicates that a better knowledge of the three dimensional distribution of different soil horizons is necessary for good management of the environment. Understanding water flow into the soil mantle is necessary for siting a drainage system that can quickly remove the excess of water during and directly after rainfall. 
Various observations in the region around Cunha indicate that this type of soil cover is widespread in the Serra do Mar. For example, it has also been identified in the neighbouring Serra da Mantiqueira, where landslide processes are again frequent (Modenesi and Motta de Toledo, 1996). A simple systematic survey by hand auger should therefore indicate the extent of areas at risk.

\section{Acknowledgements}

This research was supported by a CAPES-COFECUB cooperation. The authors thank P. Curmi, M. Grimaldi and to the reviewers for helpful criticism and advice.

\section{References}

Almeida, F.F.M., 1976. The system of continental rifts bordering the Santos basin, Brazil. In: Continental margins of atlantic type. An. Acad. Bras. Ciênc. 48, 15-26.

Bigarella, J.J., Mousinho, M.R., Silva, J.X., 1965. Considerações a respeito da evolução das vertentes. Bol. Parana. Geogr.16/17, 85-116.

Boulet, R., Chauvel, A., Humbel, F.X., Lucas, Y., 1982. Analyse structurale et cartographie en pédologie . I - Les études de toposéquences et principaux apports à la connaissance des sols. II - Une méthode d'analyse prenant en compte l'analyse tridimensionnelle des couvertures pédologiques. III - Passage de la phase analytique à une cartographie générale synthétique. Cah. ORSTOM, Sér. Pédol. 19 (4), 309-351.

Boulet, R., Curmi, P., Pellerin, J., Queiroz Neto, J.P., 1995. A contribution to an understanding of landscape development through three-dimensional morphological analysis of a pedological cover (Paulinia, State of Sau Paulo, Brazil). Géomorphol.: Relief Process. Environ. 1, 51-61.

Brewer, R., 1976. Fabric and mineral analysis of soils. R.E. Kreiger Co., New York. 
Bullock, P., Fedoroff, N., Jongerius, A., Stoops, G., Tursina, T., 1985. Handbook for soil thin section description. Waine Research Publications, Wolverhampton, UK.

Cambier, P., Prost, R., 1981. Etude des associations argile-oxide: organisation des constituants d'un matériau ferrallitic. Agronomie 1, 713-722.

Cruz, O., 1974. A Serra do Mar e o litoral na area de Caraguatatuba. Tes. Monogr. 11, IG-USP.

Curmi, P., Kertzmann, F.F., Queiroz Neto, J.P., 1994. Degradation of structure and hydraulic properties in an oxisol under cultivation (Brazil). In: Ringrose-Voase A.J., Humphreys G.S. (Eds), Soil Micromorphology: Studies in management and genesis. Proc. IX Int. Working Meeting on Soil Micromorphology, Townsville, Australia. Developments in Soil Science 22, Elsevier, Amsterdam , pp. 569-579.

Delaye, R., 1984. Notes techniques sur la préparation des lames minces dans les matériaux meubles. Bull. Inst. Géol. Bassin d'Aquitaine, Bordeaux 35, 135-158.

Delvigne, J., 1965. Pédogenèse en zone tropicale: la formation des minéraux secondaires en milieu ferrallitique. Mém. ORSTOM 13, 177 pp.

De Ploey, J., Cruz, O., 1979. Landslides in the Serra do Mar, Brazil. Catena 6, 111-122.

Eswaran, H., Daud, N., 1980. A scanning electron microscopy evaluation of the fabric and mineralogy of some soil in Malaysia. Soil Sci. Soc. Am. J. 44, 855-861.

Felicissimo, J.J., 1967. Wegener a a escarpa da Serra do Mar: intemperismo, deslizamento e erosão. Rev. IGG-USP 24, 1-10.

Fritsch, E., Fitzpatrick, E.A. 1994. Interpretation of soil features produced by ancient and modern processes in degraded landscapes: I. A new method for constructing conceptual soil-waterlandscape models. Aust. J. Soil Res. 32, 880-885 and 889-907.

Furian, S., 1987. Estudo geomorfológico do escoamento superficial pluvial em parcelas experimentais no parque Estadual da Serra do Mar, Nucleo de Cunha/SP: Um esboço metodológico. Merstrado Geografia, FFLCH-USP, São Paulo, 187 pp. 
Furian, S., 1994. Morphogenèse/pédogenèse en milieu tropical humide de la Serra do Mar, Bresil. Contribution de l'altération et de la pédogenèse à une dynamique actuelle de glissement. $\mathrm{Ph} . \mathrm{D}$. thesis Univ. Caen, 178 pp.

Furian, S., Pfeifer, R.M., 1986. Levantamento de reconhecimento do meio físico do nucleo de Cunha-SP. Bol. Tec. Inst. Flor. Sao Paulo 40 (2), 183-193.

Grimaldi, M., Boulet, R., 1990. Relation entre l'espace poral et le fonctionnement hydrodynamique d'une couverture pédologique sur socle de guyane française. Cah. ORSTOM, sér. Pédol. 25 (3), 263-275.

Guidicini, G., Iwasa, O.Y., 1976. Eusaio de correlação entre pluviosidade e escorregamentos em meio tropical úmido. Publicação IPT 1080, São Paulo, 48 pp.

Guidicini, G., Nieble, C.M., 1976. Estabilidade de tabules naturais e de escavações. In: Blücher H., Ed C. (Eds), USP São Paulo, 170 pp.

Hallaire, V., Curmi, P., 1994. Image analysis of pore space morphology in soil sections in relation to water movement. In: Ringrose-Voase A.J., Humphreys G.S. (Eds), Soil Micromorphology: Studies in management and genesis. Proc. IX Int. Working Meeting on Soil Micromorphology, Townsville, Australia, Developments in Soil Science 22, Elsevier, Amsterdam, pp. 559-567.

Keller, W.D., Clark, O.M., 1984. Resilication of bauxite at the Alabama street mine, Saline County, Arkansas, illustrated by scanning electron micrographs. Clays and Clay Min. 32, 139-146.

Lucas, Y., 1989. Systèmes pédologiques en Amazonie Brésilienne. Equilibres, déséquilibres et transformations. Ph.D. Thesis, Univ. Poitiers, 177 p.

Lucas, Y., Kobilsek, B., Chauvel, A., 1989. Structure, genesis and present evolution of Amazonian bauxites developed on sediments. 6. International Congress of ICSOBA, Poços de Caldas, Brazil, 19, 81-94. 
Modenesi, M.C., Motta de Toledo, M.C., 1996. Weathering and the formation of hillslope deposits in the tropical highlands of Itatiaia, southeastern Brazil. Catena 27, 81-103.

Monnier, G., Stengel, P., Fies, J.C., 1973. Une méthode de mesure de petits agglomérats terreux. Application à l'analyse des systèmes de porosité du sol. Ann. Agron. 24, 533-545.

Moyersons, J., 1989. Les glissements de terrain au Rwanda occidental. Leurs causes et les possibilités de leur prévention. Cah. ORSTOM, Sér. Pédol. 25, 131-149.

Souza Sobrinho, R. R. de, 1988. Uma abordagem em direção à previsão de movimentos de massa: caso da Rio-Santos (Trecho Itaguaí - Conceição de Jacareí). Geociênc. 7, 43-76.

Tessier, D., 1978. Technique d'étude de l'orientation des particules argileuses utilisable sur des échantillons secs ou humides. Ann. Agron. 29, 193-207.

Tessier, D., Berrier, J., 1979. Utilisation de la microscopie électronique à balayage dans l'étude des sols. Observations de sols humides, soumis à différents pF. Sci. du Sol 1, 67-82.

Wiebel, E.R., 1979. Stereological methods. Vol. 1. Practical methods for biological morphometry. Academic Press, London.

Table 1: Porosity and water retention at $\mathrm{pF} 2$ and 3 of the gibbsitic $(\mathrm{G})$, kaolinitic $(\mathrm{K})$ and microaggegated $(\mathrm{M})$ horizons.

Fig. 1. Location of the study site in the Serra do Mar (southeastern Brazil).

Fig. 2. Distribution of the main horizons along toposequence 2.

1 - Superficial burrowed and blocky horizons; 2 - K Horizons within G horizon; 3 - Parent rock;

4 - G Horizons; 5 - M Horizons (mh1 and mh2); 6 - Downslope domain.

Fig.3 . Box-work structure resulting from gibbsite pseudomorphs $(Q=q u a r t z, G=$ gibbsite, $V=$ voids)

Fig. 4. Detail of the box-work organisation $(\mathrm{G}=$ gibbsite, $\mathrm{I}=$ Iron oxide, $\mathrm{V}=$ voids $)$ 
Fig. 5. Detail of the contact between K and G horizons.

Fig. 6. Scanning electron micrograph of the dissolution pattern of gibbsite at the contact between $\mathrm{K}$ and G horizons.

Fig. 7. Scanning electron micrograph showing detail of the dissolution pattern of gibbsite at the contact between $\mathrm{K}$ and $\mathrm{G}$ horizons. Former structural faces are recognisable.

Fig. 8. Scanning electron micrograph of the dissolution patterns of quartz at the contact between K and G horizons.

Fig. 9. Scanning electron micrograph of the detailed dissolution pattern of quartz showing pyramidal etch pits.

Fig. 10. Remnants of the gibbsitic box-work associated with unweathered minerals such as hornblende, other amphiboles, microcline, muscovite and biotite $(\mathrm{G}=$ gibbsite, $\mathrm{Q}=$ quartz, $\mathrm{M}=$ microcline, $\mathrm{Mu}=$ muscovite)

Fig. 11. Distribution of the $\mathrm{K}$ and $\mathrm{G}$ horizons in the upslope domain, and areas of the downslope domain. Map based on sequences 1, 2, 3 and 5 .

1 - G horizons; 2 - K horizons within G horizon; 3 - Downslope domain; 4 - Toposequence.

Fig. 12. Mercury porosimetry curves of $\mathrm{K}, \mathrm{G}$ and $\mathrm{M}$ horizons: differential and cumulative pore volumes shown as a function of calculated pore radius.

Fig. 13. Distribution, size and connectivity of the macroporosity of the K Horizon (a and b) and microaggregated (M) horizons mh1 (c) and mh2 (d). Voids shown in black.

Fig. 14. Water retention $\mu$ and shrinkage curves $\lambda$ of $K$ and $M$ horizons.

Fig. 15. Model proposed for the contribution of weathering and pedogenesis to landslide processes. a) Vertical drainage predominates - low risk of landslide on the slope; b) lateral drainage increases medium risk of landslide on the slope; c) lateral drainage predominates - high risk of landslide on the slope. 
1 - K horizons; 2 - M horizons; 3 - Water flows; 4 - Lateral evolution of the K horizons; 5 Landslide. 


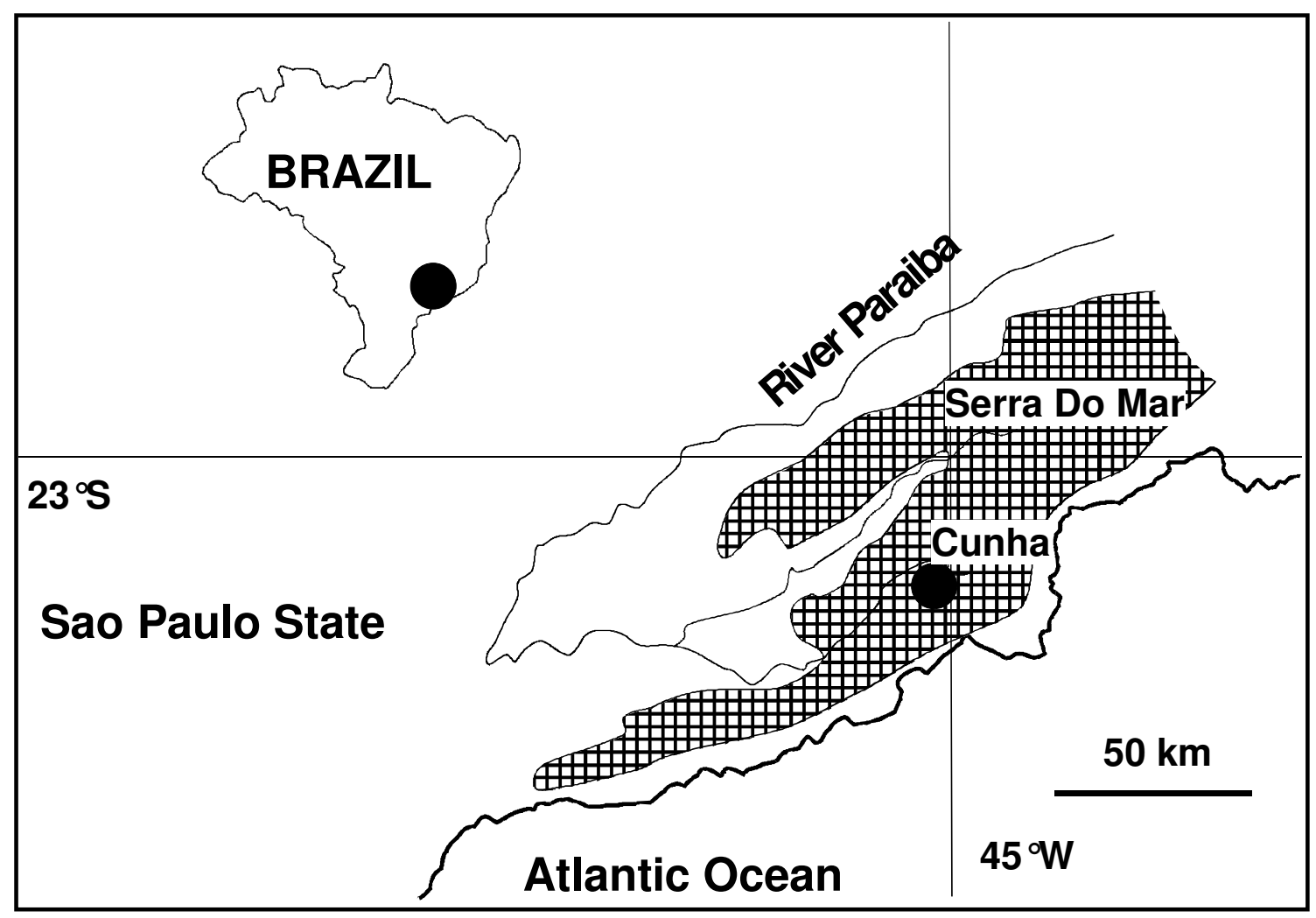



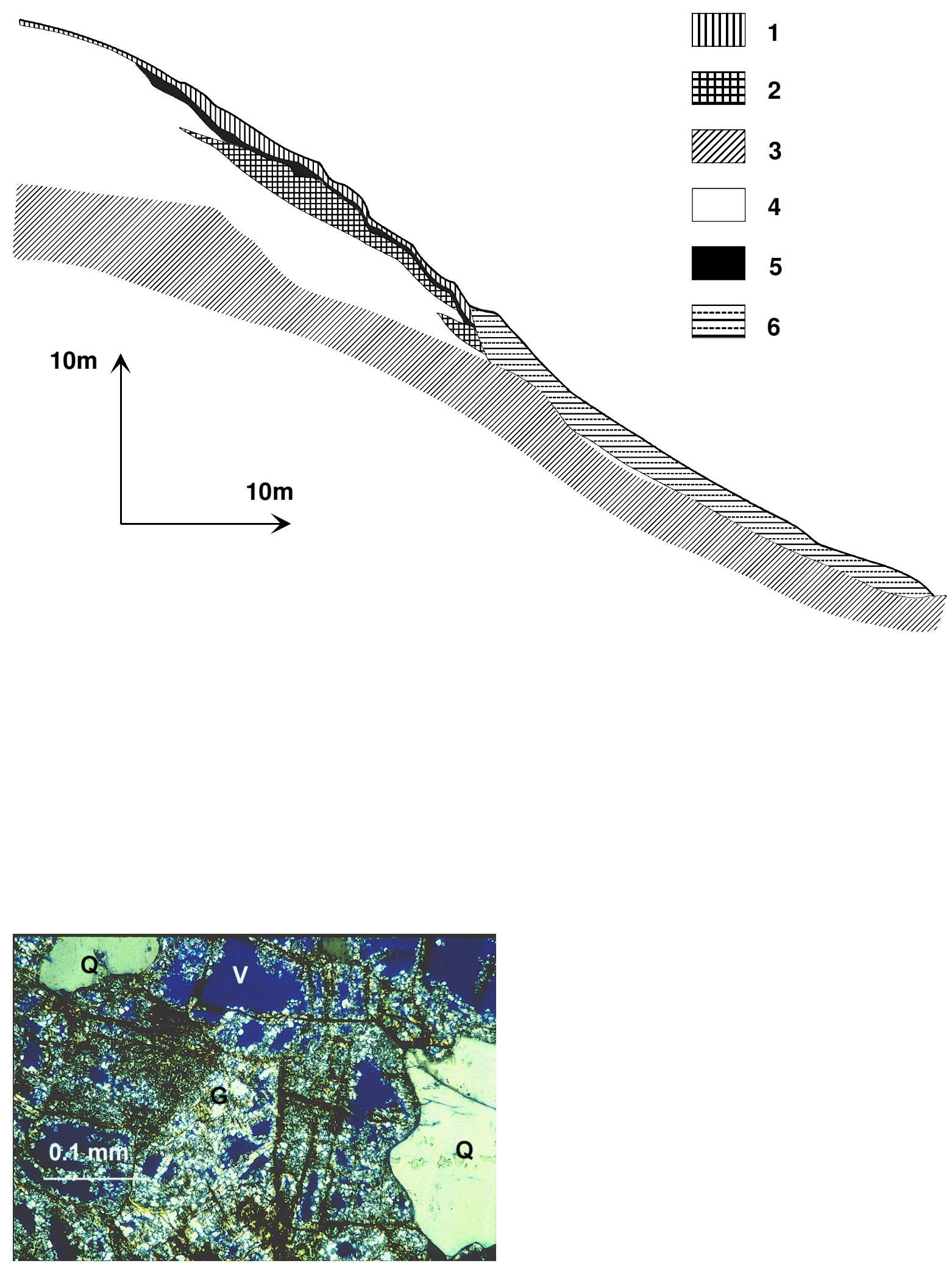

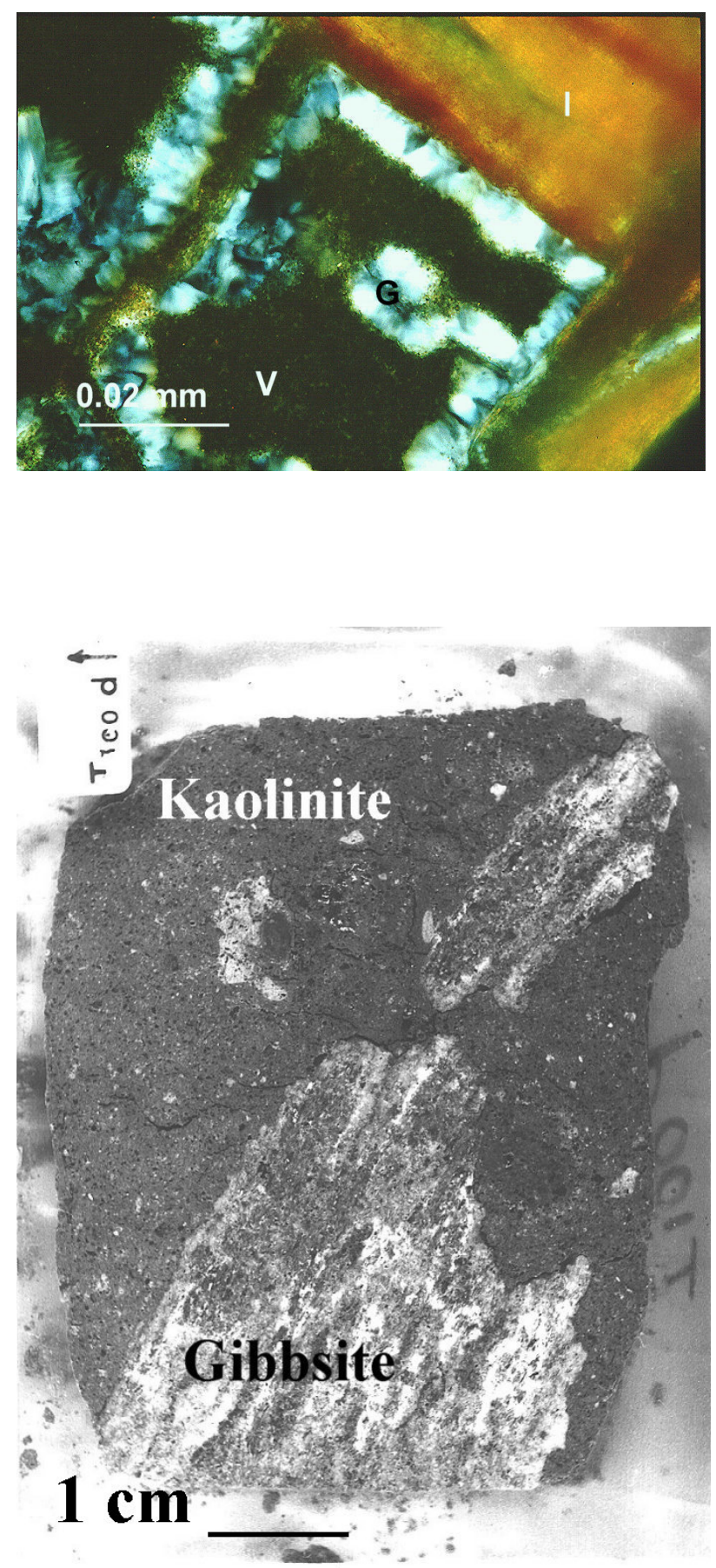

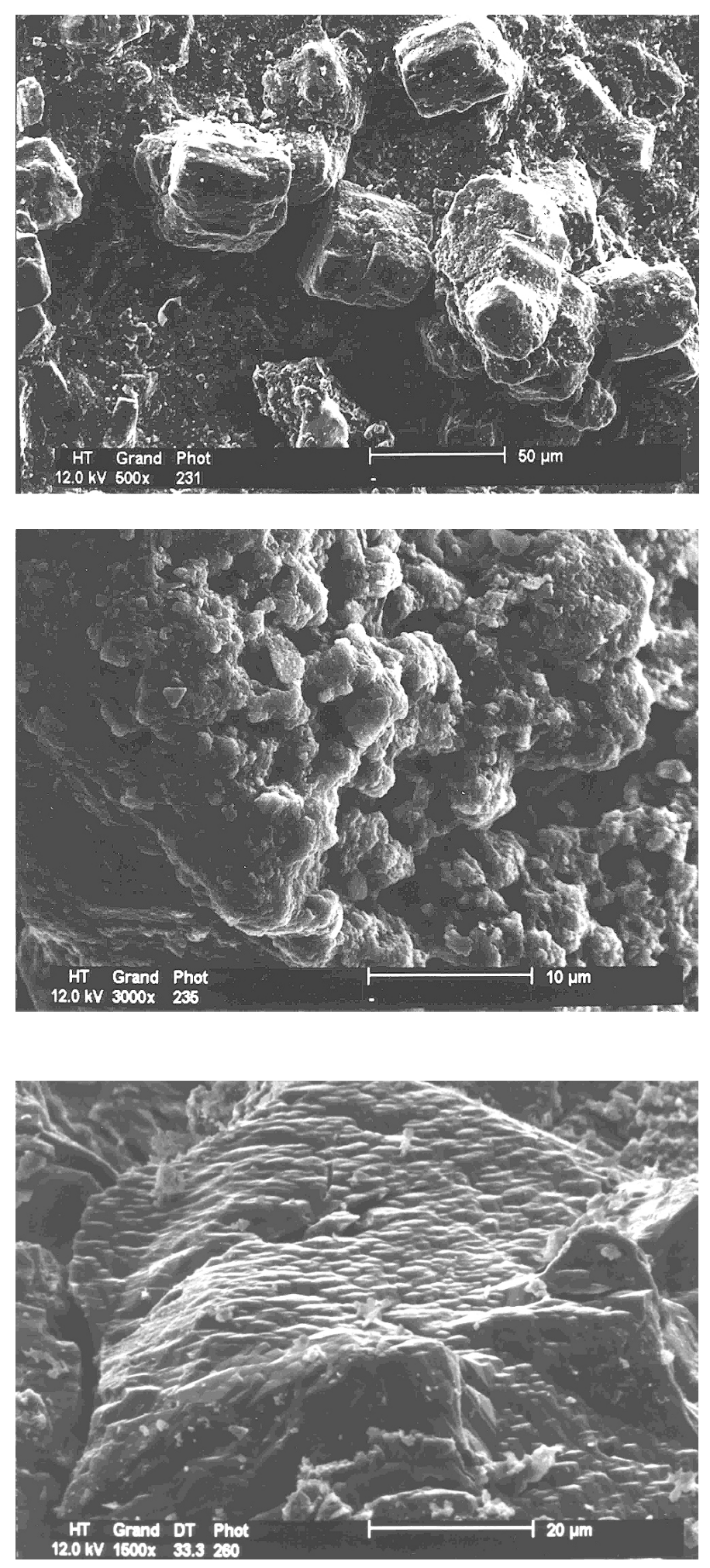

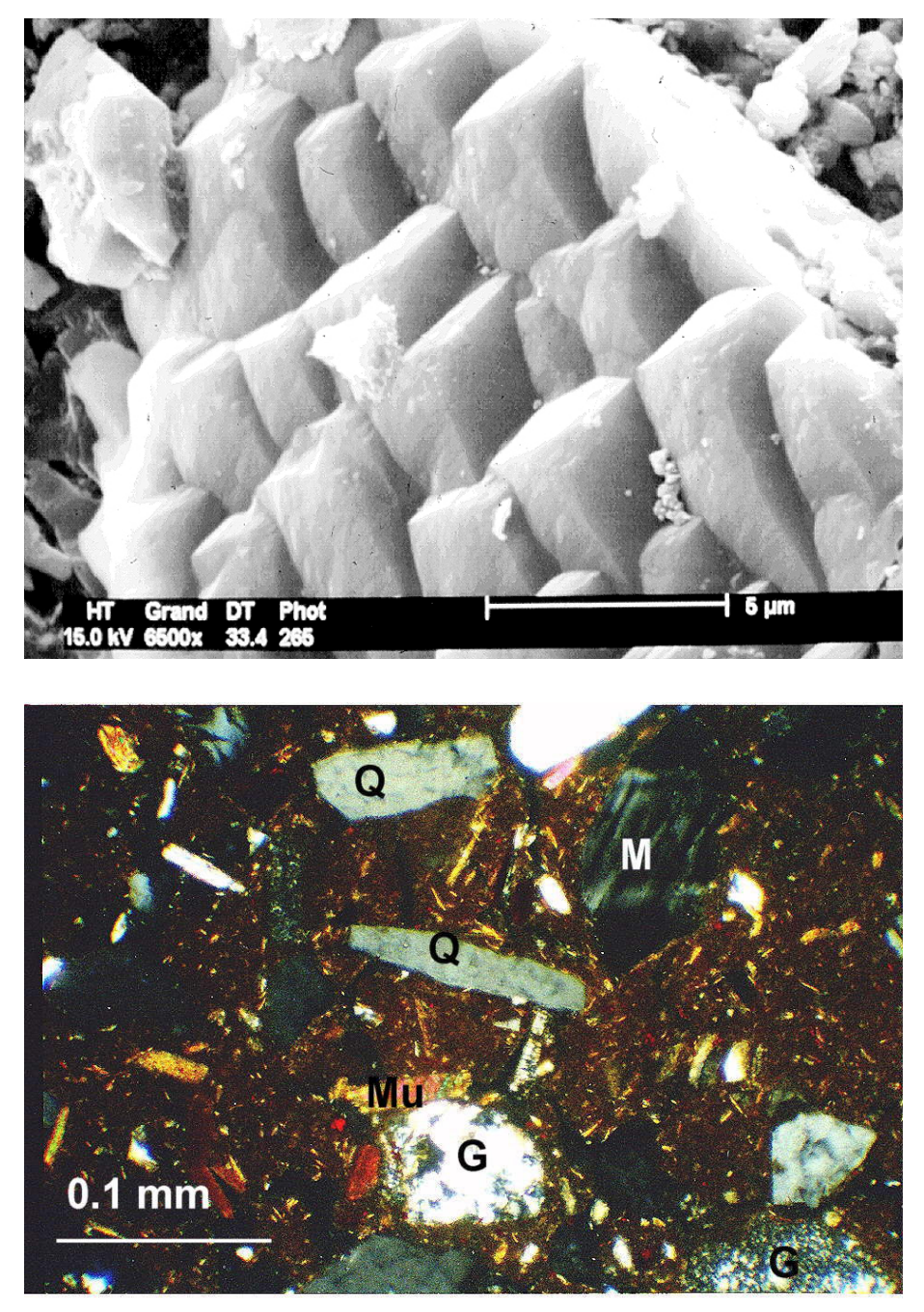


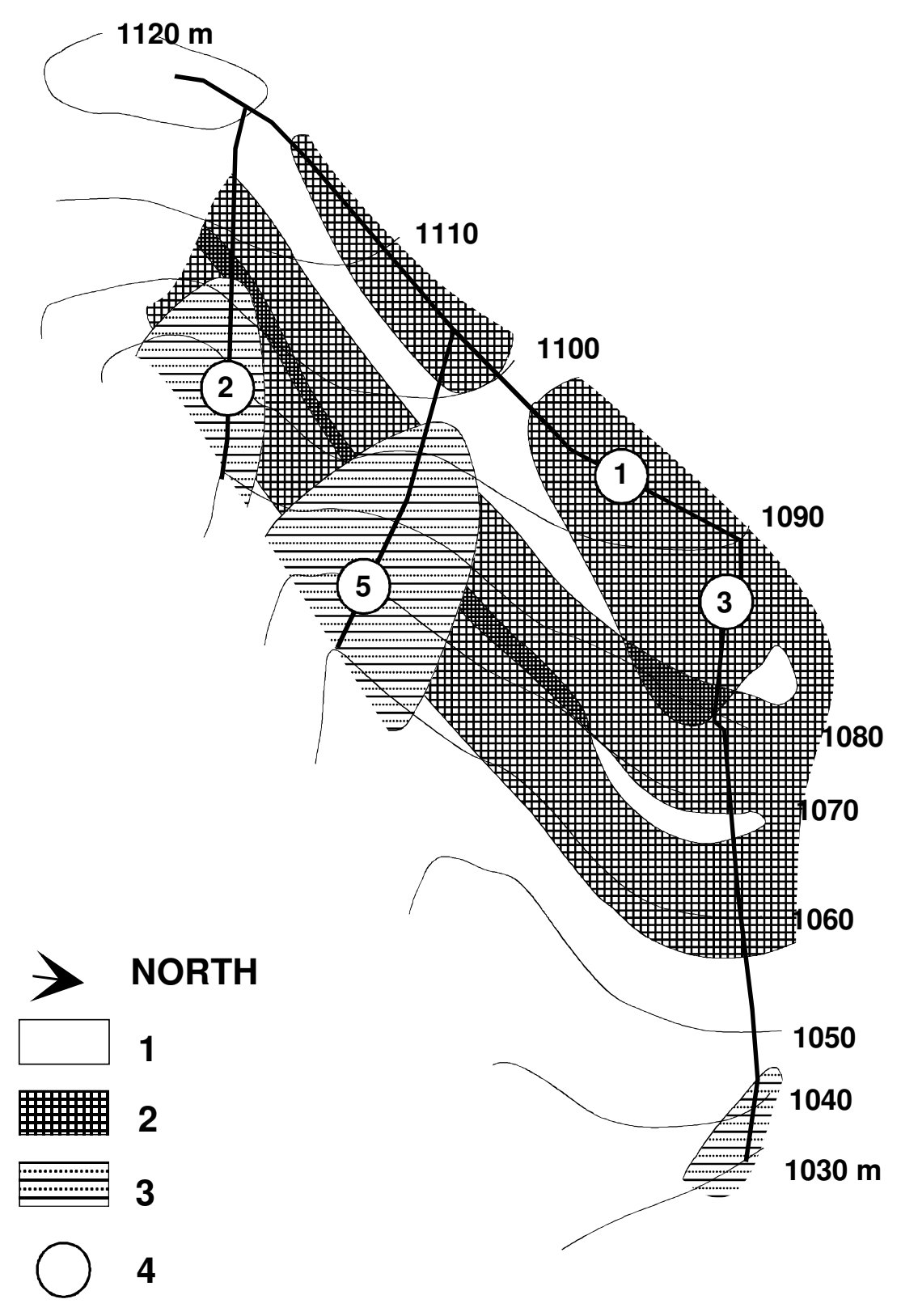



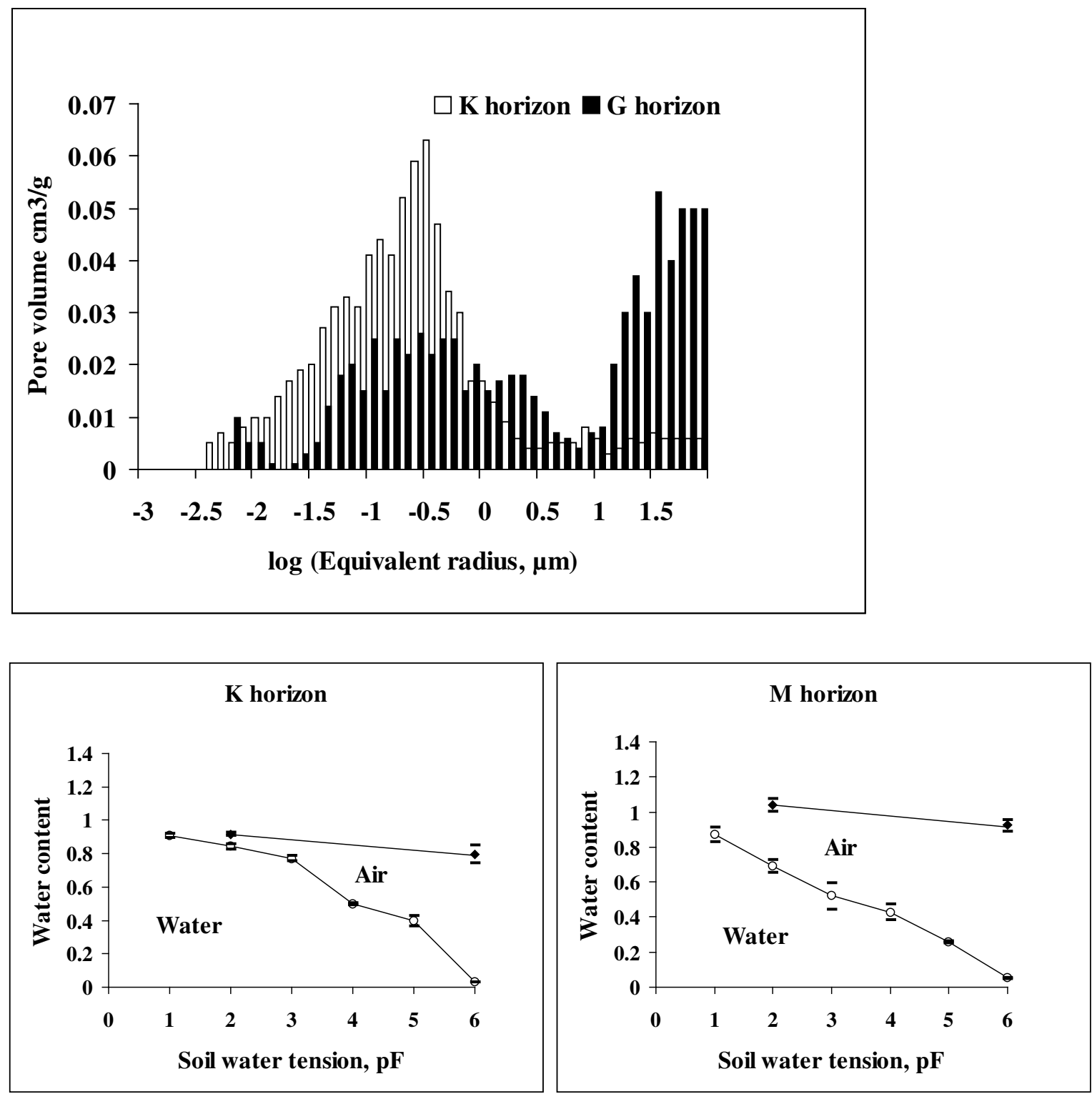


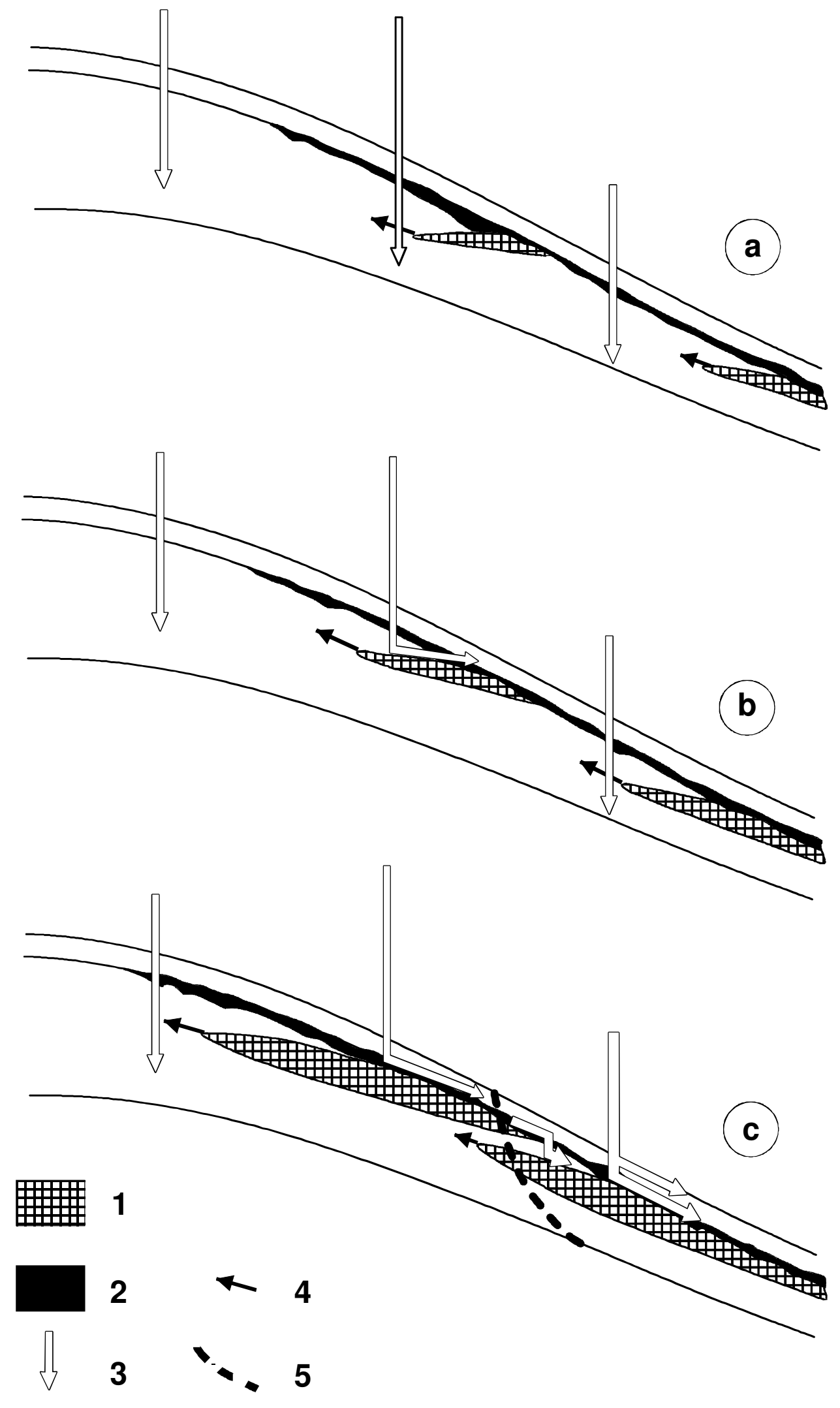

